\title{
TRUE GLUCOSE CONTENT OF LUMBAR AND VENTRICULAR CEREBROSPINAL FLUID
}

\author{
BY \\ VINCENT MARKS \\ From the Department of Chemical Pathology, Institute of Neurology, National Hospital, \\ Queen Square, London
}

(RECEIVED FOR PUBLICATION JULY 2, 1959)

\begin{abstract}
Glucose levels in 154 random specimens of lumbar cerebrospinal fluid, normal as regards cell and protein content, were estimated by the glucose-oxidase method and a mean value of $60.5 \mathrm{mg}$./100 ml. (S.D. 7.3) was obtained.

In 33 fasting patients subject to air encephalography the mean cerebrospinal fluid (C.S.F.) glucose level was $56.5 \mathrm{mg}$., and mean blood glucose level $65.5 \mathrm{mg}$. with an aveiage C.S.F. glucose: blood glucose ratio of 0.85 .
\end{abstract}

Estimation of the glucose content is a valuable adjunct to the enumeration and identification of cells and the determination of the protein content of cerebrospinal fluid (C.S.F.) as a diagnostic procedure. In the past, differences of opinion have existed as to the normal levels of glucose, and this has been in part due to the lack of a specific method for determining this substance in biological fluids. Recently methods utilizing glucose-oxidase have been employed for blood. Results of such estimations show that glucose is invariably present in smaller amounts than had previously been found using non-specific methods. This paper describes the normal ranges of C.S.F. glucose and compares them with glucose levels in venous blood.

\section{Material}

Glucose estimations were performed on 154 specimens of C.S.F. received in the laboratory. No preservatives were used, and estimations were completed within a few hours of the C.S.F. being drawn. Only fluids which were normal in all respects, such as cell count and protein, were used. These fluids were obtained at various times of the day and bore no fixed time relationship to food intake.

In addition 63 ventricular fluids were obtained at diagnostic ventriculography, usually under local anaesthetic (which often contained adrenaline), or immediately preceding major surgery. All these patients were in the fasting state. Cell and protein content was frequently normal, but slightly abnormal fluids, i.e., those containing less than 10 cells $/ \mathrm{mm}$. and $60 \mathrm{mg} . \%$ protein, were not excluded from analysis. Grossly abnormal fluids are not considered in this communication.
Thirty-three lumbar fluids, normal as regards cell and protein content, were obtained from patients subjected to diagnostic air encephalography. Most of these patients were not anaesthetized though heavily

TABLE I

GLUCOSE LEYELS MEASURED BY GLUCOSE-OXIDASE AND FOLIN-WU METHODS IN C.S.F. AND VENOUS BLOOD

\begin{tabular}{|c|c|c|c|c|c|}
\hline \multirow{2}{*}{$\begin{array}{l}\text { Case } \\
\text { No. }\end{array}$} & \multicolumn{2}{|c|}{ Cerebrospinal Fluid } & \multicolumn{2}{|c|}{ Blood } & \multirow{2}{*}{$\begin{array}{c}\text { C.S.F./ } \\
\text { Glood } \\
\text { Racose }\end{array}$} \\
\hline & $\begin{array}{l}\text { Glucose- } \\
\text { oxidase } \\
\text { Method }\end{array}$ & $\begin{array}{c}\text { Folin- } \\
\text { Wu } \\
\text { Method }\end{array}$ & $\begin{array}{l}\text { Glucose- } \\
\text { oxidase } \\
\text { Method }\end{array}$ & $\begin{array}{c}\text { Folin- } \\
\text { Wu } \\
\text { Method }\end{array}$ & \\
\hline $\begin{array}{r}1 \\
2 \\
3 \\
4 \\
5 \\
6 \\
7 \\
8 \\
9 \\
10 \\
11 \\
12 \\
13 \\
14 \\
15 \\
16 \\
17 \\
18 \\
19 \\
20 \\
21 \\
22 \\
23 \\
24 \\
25 \\
26 \\
27 \\
28 \\
29 \\
30 \\
31 \\
32 \\
33\end{array}$ & $\begin{array}{l}46 \\
48 \\
49 \\
50 \\
50 \cdot 5 \\
51 \\
53 \\
54 \\
54 \cdot 5 \\
55 \\
55 \\
56 \\
56 \\
56 \cdot 5 \\
57 \\
57 \\
57 \cdot 5 \\
57 \cdot 5 \\
58 \\
58 \\
58 \\
58 \\
58 \cdot 5 \\
58 \cdot 5 \\
59 \\
59 \\
60 \\
60 \\
61 \\
62 \\
64 \\
64 \\
65\end{array}$ & $\begin{array}{l}53 \cdot 5 \\
56 \\
52 \\
51 \\
58 \\
59 \\
55 \cdot 5 \\
64 \\
62 \\
59 \\
70 \\
60 \\
62 \\
66 \\
70 \\
67 \\
56 \\
87 \\
93 \\
65 \\
66 \\
70 \\
64 \\
86 \\
76 \cdot 5 \\
63 \\
75 \\
77 \\
71 \\
70\end{array}$ & $\begin{array}{l}53 \\
60 \\
59 \\
62 \\
66 \cdot 5 \\
53 \\
57 \\
69 \\
68 \\
65 \\
67 \\
63 \\
56 \\
59 \\
75 \\
64 \\
58 \\
71 \\
68 \\
68 \\
62 \\
77 \\
58 \\
65 \\
67 \\
67 \\
68 \\
65 \\
67 \cdot 5 \\
83 \\
78 \\
68 \\
68\end{array}$ & 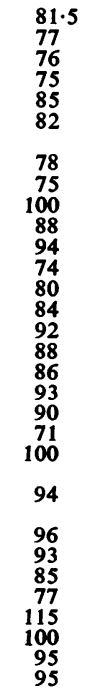 & $\begin{array}{l}0.86 \\
0.80 \\
0.83 \\
0.81 \\
0.80 \\
0.97 \\
0.93 \\
0.78 \\
0.80 \\
0.85 \\
0.82 \\
0.89 \\
1.00 \\
0.96 \\
0.76 \\
0.89 \\
0.99 \\
0.82 \\
0.85 \\
0.85 \\
0.94 \\
0.75 \\
1.00 \\
0.90 \\
0.88 \\
0.88 \\
0.89 \\
0.92 \\
0.91 \\
0.74 \\
0.82 \\
0.94 \\
0.96\end{array}$ \\
\hline Mean & $56 \cdot 5$ & $67 \cdot 7$ & $65 \cdot 5$ & $88 \cdot 0$ & 0.85 \\
\hline
\end{tabular}

* Levels are expressed as $\mathrm{mg}$. glucose per $100 \mathrm{ml}$. fluid. 
sedated ; all were fasting. Immediately before lumbar puncture a sample of venous blood was drawn into a bottle containing $0.03 \mathrm{ml}$. of $8 \%$ formalin. Blood and C.S.F. were analysed by both the glucose oxidase and Folin-Wu methods.

\section{Methods}

Glucose was determined in blood and C.S.F. by the method previously described (Marks, 1959). "Glucose" was determined by a modified method of Folin and Wu (Harrison, 1947).

\section{Results}

Since the conditions under which the fluids in each group were collected differ so markedly, it is not possible to attach statistical significance to the observations in one group compared with those in another.

Results for true glucose estimations of 154 normal lumbar C.S.F. and 63 ventricular fluids are shown in Fig. 1. Mean glucose levels of $60.5 \mathrm{mg} . / 100 \mathrm{ml}$. (S.D. 7.3) for lumbar and $61.2 \mathrm{mg} . / 100 \mathrm{ml}$. (S.D. 11.3) for ventricular fluid were obtained.

Cerebrospinal fluid obtained at air encephalography from fasting patients showed a mean glucose level of $56.5 \mathrm{mg}$./100 ml. (S.D. 4.5), and the mean fasting blood glucose level was $65.5 \mathrm{mg} . /$ $100 \mathrm{ml}$. (S.D. 6.4). The average ratio of glucose in C.S.F. to blood was 0.85 (S.D. $=0.075$ ).

In five patients, in whom the fluid was otherwise normal, ventricular glucose levels between 35 and $40 \mathrm{mg}$. $/ 100 \mathrm{ml}$. were found. Except in one case, a patient with a pituitary tumour and reduced blood sugar, no explanation for these apparently low levels is available. In C.S.F. from fasting patients true glucose was always lower than glucose estimated by the Folin-Wu method, by an average of $11.2 \mathrm{mg} . / 100 \mathrm{ml}$. In a previous report (Marks, 1959) on a smaller group of patients who were not fasting an average difference of $5.5 \mathrm{mg} . / 100 \mathrm{ml}$. was found.

\section{Discussion}

Although the propriety of considering C.S.F. from patients with disease of the nervous system as normal is questionable, the ethical difficulties in obtaining normal C.S.F. from healthy people has made it necessary to resort to considering C.S.F., normal as regards cell and protein content, as "normal" for the purpose of further analysis.

Katzenelbogen (1935), Lups and Haan (1954), and others have insisted that for the sugar content

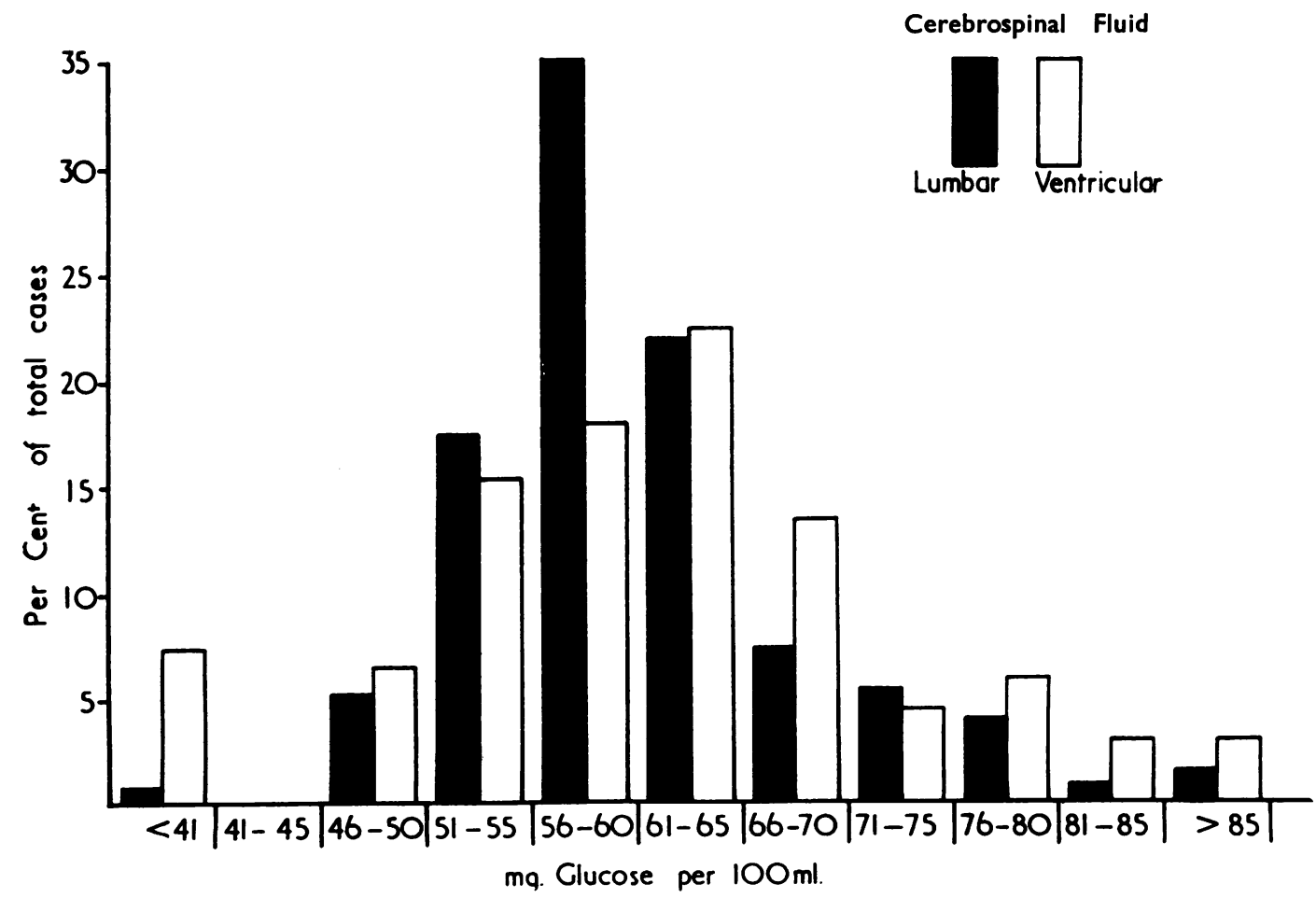

FIG. 1.-Distribution of true glucose in 154 lumbar and 63 ventricular fluids. 
of C.S.F. to be of significance in diagnosis the fluid should be obtained from the fasting patient because they believe that it is directly related to the blood sugar level at any one time. However, Cumings and Carmichael (1934) in a series of experiments showed that slight elevations of blood sugar in the human subject following the administration of oral glucose were not accompanied by significant changes in the C.S.F. The present findings, that C.S.F. glucose levels in fasting and non-fasting patients do not differ greatly from each other, agree with these experimental results. Glucose elevations (and possibly depressions over a long period) are, however, attended by a proportionate change in the C.S.F. level of glucose.

I should like to thank Professor J. N. Cumings for his help and advice in the preparation of this paper.

\section{REFERENCES}

Cumings, J. N., and Carmichael, E. A. (1934). Brain, 57, 338. Harrison, G. A. (1947). Chemical Methods in Clinical Medicine. 3rd ed. Churchill, London.

Katzenelbogen, S. (1935). The Cerebrospinal Fluid and Its Relation to the Blood. Johns Hopkins Press, Baltimore.

Lups, S., and Haan, A. M. F. H. (1954). The Cerebro-Spinal Fluid. Elsevier, Amsterdam.

Marks, V. (1959). Clin. Chim. Acta, 4, 395. 